\title{
Effects of High Altitude on Morphophysiological Patterns, Perception and Attention Capacity in Students from Putre (3500 m.a.s.l.) and Arica (2 m.a.s.l.), Chile
}

\author{
Efectos de la Altura sobre Patrones Morfofisiológicos y en la Capacidad Atencional y de Percep- \\ ción en Estudiantes de las Comunas de Putre $(3500 \mathrm{msnm})$ y de Arica $(2 \mathrm{msnm})$, Chile
}

Espinoza-Navarro, $\mathrm{O}^{*}$ \& Graú, $\mathrm{S}^{* * *}$

ESPINOZA-NAVARRO, O \& GRAÚ, S. Effects of high altitude on morphophysiological patterns, perception and attentional capacity in students from Putre (3500 m.a.s.1.) and Arica (2 m.a.s.1.), Chile. Int. J. Morphol., 32(2):593-598, 2014.

SUMMARY: High altitude hypoxia is a stress that triggers several adaptive mechanisms, one of which is how the brain responds to lack of oxygen. The aim of this study was to determine changes in morphological and physiological patterns and in the attention capacity and perception in student populations from the highlands and from a sea level location. Eighty students, aged 14 to 16 years old, both sexes, from the Municipalities of Putre (3500 m.a.s.1.) and Arica (2 m.a.s.l.) participated in this study, with each group composed of 20 women and 20 men. After informed consent was obtained and with the students acceptance, parameters such as weight, height, BMI, heart rate, systolic and diastolic blood pressures were obtained. Subsequently, a psychometric test of attention and perception was applied. The results determined that the population from Putre had less weight and height than students from Arica. Males exhibited a significant decrease in heart rate and women had lower systolic and diastolic blood pressures than in the assessed sea level population. The levels of response in the psycho-technical tests were significantly lower in the population from high altitude, both in males and females. We conclude that high altitude causes changes in morphological and physiological patterns and in responsiveness in psycho-technical tests. However, further studies in psycho-perception are required to delineate the effects that are unique of ethnicity, culture and worldview of the people living in high altitude and their levels of response.

KEY WORDS: Altitude; Andean highlands; Attentional capacity; Psychometrics; Chile.

\section{INTRODUCTION}

High altitude represents an extreme environment, where several factors such as hypoxia, thermal amplitude, low humidity, low nutritional value and high solar radiation are combined. Populations living in this environment interact with all the variables. The human being -despite our great adaptability to adverse environments- has limitations with hypoxia being one of the most important (Espinoza-Navarro et al., 2011).

Authors agree in determining as a parameter for high altitude the fact of living above 2500 meters above sea level (m.a.s.1.). When altitude increases, a reduction in the degree of oxygen saturation is observed, which implies that hemoglobin is carrying less oxygen; however, in highland populations adaptive mechanisms such as an increment in the amount of hemoglobin and a higher affinity of hemoglobin for oxygen are under constant function, thus allowing adequate oxygenation of the cells (Beall, 2006; Hogan et al., 2010; Verges, 2012).

One of the problems that has increasing importance in altitude physiology is how the brain and its cells behave in the presence of this strong stress. Some authors have described a low metabolic rate and a better use of energy in these structures (Hochachka et al., 1994). Wolff (2000) found a balance between vasodilation and vasoconstriction in blood vessels that irrigate the brain. In the same context, LaManna et al. (2004) in studies performed in rats observed that the ideal adaptive response would be an increased capillarization of the nervous system. Hornbein (2001) indicated that hypoxia always causes a deterioration of brain cells, which can be measured thru the performance in neuropsychometric tests. A review by Bass et al. (2004), showed that $78.2 \%$ of

\footnotetext{
* Faculty of Sciences, Department of Biology, Universidad de Tarapacá, Arica, Chile.

${ }^{*}$ School Education in Biology and Life Sciences Universidad de Tarapacá, Arica, Chile.
} 
the studies analyzed expressed an adverse effect of high altitudes on the behavior of neuronal cells. Hogan et al., observed in a population of children and adolescents from highlands a small reduction in psychomotor speed as altitude increased, possibly due to the slowdown in brain function and to the brain reduced metabolism. This may alter the perception and attentional capacity in people living in high altitude.

In Chile, like Peru, Bolivia and Argentina, the highland environment is caused by the influence of the Andean mountain chain called Altiplano. The town of Putre, with a population of 1,203 inhabitants, is located at 3500 m.a.s.l.; its population consists of approximately $60 \%$ of Aymaras. Arica, three hours away from Putre, is a city of 150,000 inhabitants located at an altitude of 2 m.a.s.l. (INE, 2002).

The objective of this research was to compare the patterns of weight, height, body mass index (BMI), blood pressure (BP), heart rate (HR) and attentional capacity and perception of young people between 14 and 16 years old (both sexes) living in Putre (3500 m.a.s.l.) in relation to young people from Arica (2 m.a.s.l.).

\section{MATERIAL AND METHOD}

The Ethics/Bioethics Committee from the Universidad de Tarapacá approved the protocol and methodology of this research. Eighty (80) male and female students of the Liceo Granaderos school of Putre $(n=40)$ and from Liceo Domingo Santa María school of Arica $(n=40)$, all aged between 14-16 years old, were participants in this study. After the signature of informed consent by the directors, heads of the Education Technical Units, teachers, parents and assent from students, we proceeded to collect the data.

The assessment of the individuals was held during morning sessions, in their respective schools and separately for boys and girls. For weight and height determination, we used a medical stadiometer with incorporated scale (Fitness, model D-339.2, USA). Students were assessed in light clothing, barefoot and anatomically positioned.

The body mass index (BMI) was calculated according to the formula of weight $(\mathrm{kg})$ divided by height $(\mathrm{m})$ squared $(\mathrm{kg} / \mathrm{m} 2)$ and thus the participants were classified as thin, normal, overweight and obese (Olivares, 2002). Records of physiological samples such as blood pressure (BP) and heart rate (HR) were registered by a digital tensiometer (GA.MA Italy Professional), while the tested subject was sitting on a chair while his left elbow lied on the examination surface (table) and his wrist was positioned parallel to his heart.
To measure attentional capacity and perception in students, the psycho-technical test for attention and perception (http://www.psicoactiva.com/tests/t1.htm) was applied, which consists in marking the row and/or column in a series of table charts where the same letter was repeated one or more times, consisting each table of 4 rows and 4 columns, as shown in Figure 1. This psychometric test is formed by 30 charts in total. The time to perform the test was 5 minutes. To evaluate the results achieved, a score parameter of 52 points maximum, which corresponds to $100 \%$ of correct answers, was considered; each wrong answer deducted a point and blank answers were not evaluated. The final score was classified according to Table I. Results were recorded and statistically analyzed according to SPSS 14.0 (2006).

Table I. Evaluation of the capacity of attentional response and perception. Maximum score of 52 points, which corresponds to $100 \%$ correct answers (http:// www.psicoactiva.com/tests/t1.htm).

\begin{tabular}{ccc}
\hline Score & $\begin{array}{c}\text { Levels of attentional } \\
\text { capacity and perception }\end{array}$ & $\begin{array}{c}\text { Percentage } \\
\text { values }\end{array}$ \\
\hline $52-47$ & Excellent & $100-90$ \\
$46-42$ & Good & $89-80$ \\
$41-36$ & Medium & $79-70$ \\
$35-31$ & Low & $69-60$ \\
$\leq 30$ & Precarius & $\leq 60$ \\
\hline
\end{tabular}

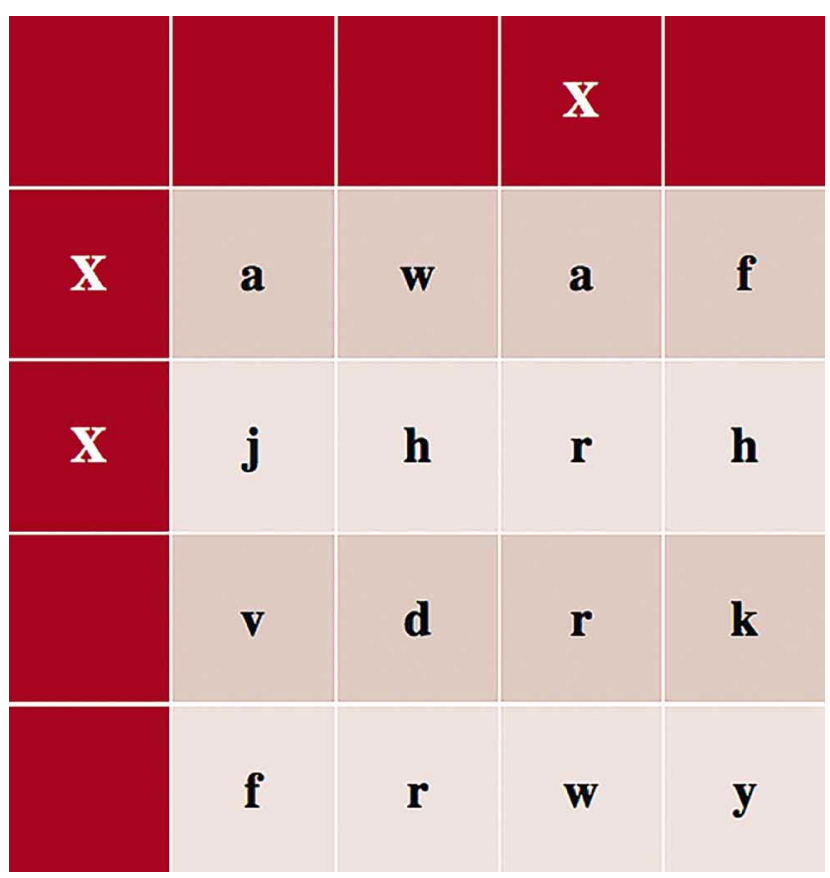

Fig. 1. Psycho-technical test for attention and perception. Indications required marking the row(s) and/or column(s) in tables where the subject detected the same letter repeated once or more times. Each table consists of 4 rows and 4 columns. The full test consists of 30 tables (http://www.psicoactiva.com/tests/t1.htm). 


\section{RESULTS}

In Table II shows the mean \pm standard deviation achieved by male and female students from Arica, where a significant decrease in weight and height in women compared to men was observed; however, both sexes exhibited normal body mass indexes (BMI). Regarding physiological outcomes, no statistically significant differences were seen in blood pressure (BP) or heart rate (HR). Regarding the results of the psycho test of attention and perception, no significant differences between groups were observed ( $82.21 \%$ to $82.45 \%$ for ladies and men, both values with "good levels of response").

In Table III compares the parameters obtained in the population from Putre (male and female students), where a significant decrease was observed in the size of the women compared to men. Both groups had normal BMI. A significantly higher diastolic blood pressure in men was observed, which also showed a significant decrease in heart rate records. The psycho-test results showed no sex-related differences in students from Putre (75.55\% for the women, "medium levels of response" and 66,51\% for males, "low levels of response".

In Table IV presents the results obtained in women from Putre and Arica and shows significant differences in height and weight between them, with the female students of Putre registering lower weights and heights. In the case of blood pressure (systolic and diastolic), a significant decrease in the women from Putre was determined. No significant difference was shown in heart rate (HR). In the psycho-test, a significant decrease in the levels of response from women of Putre is depicted (medium levels of response compared to the women from Arica with good levels of response).

In Table $\mathrm{V}$ shows the average values obtained in men from the communes of Putre and Arica. Statistically significant differences in size and weight were observed the male students from Putre registering lower mean heights and weights-, and also a significant decrease in heart rate and significantly lower results in attentional capacity and perception indices, compared to men of Arica, were determined (66.51\% and $82.45 \%$, respectively).

Table II. Overall results (mean \pm standard deviation) for morphological and physiological patterns and of attention and perception assessments by sex in students from Arica, Chile $(* \mathrm{p}<0.05 ; * * \mathrm{p}<0.01)$.

\begin{tabular}{lcccccccc}
\hline Sex & $\begin{array}{c}\text { Age } \\
(\mathbf{y} \text { ears) }\end{array}$ & $\begin{array}{c}\text { Stat ure } \\
(\mathbf{m})\end{array}$ & $\begin{array}{c}\text { Weight } \\
\mathbf{( k g})\end{array}$ & $\begin{array}{c}\text { BMI } \\
\left(\mathbf{k g} / \mathbf{m} \_\right.\end{array}$ & $\begin{array}{c}\text { Diastolic blood } \\
\text { pressure } \\
(\mathbf{m m H g})\end{array}$ & $\begin{array}{c}\text { Systolic blood } \\
\text { pressure } \\
(\mathbf{m m H g})\end{array}$ & $\begin{array}{c}\text { Heart rate } \\
(\mathbf{b e a t s} / \mathbf{m i n})\end{array}$ & $\begin{array}{c}\text { Psycho- } \\
\text { technical test } \\
(\mathbf{\%})\end{array}$ \\
\hline Female & 15 & 1.61 & 58.5 & 22.76 & 82.9 & 123.2 & 82.4 & 82.21 \\
& \pm 0.89 & \pm 0.06 & \pm 6.91 & Normal & \pm 11.64 & \pm 9.92 & \pm 11.65 & \pm 9.36 \\
Male & 15 & $\mathbf{1 . 6 7}$ & $\mathbf{6 5 . 7}$ & 23.27 & 81.7 & 126 & 74.9 & 82.45 \\
& \pm 0.66 & $\mathbf{\pm 0 . 0 7 * *}$ & $\mathbf{\pm 1 3 . 8 3 *}$ & Normal & \pm 10.59 & \pm 14.61 & \pm 12.76 & \pm 12.46 \\
\hline
\end{tabular}

Table III. Overall results (mean \pm standard deviation) for morphological and physiological patterns and of attention and perception assessments by sex in students from Putre, Chile $(* \mathrm{p}<0.05 ; * * \mathrm{p}<0.01)$.

\begin{tabular}{lcccccccc}
\hline Sex & $\begin{array}{c}\text { Age } \\
(\mathbf{y e a r s})\end{array}$ & $\begin{array}{c}\text { Stature } \\
(\mathbf{m})\end{array}$ & $\begin{array}{c}\text { Weight } \\
\mathbf{( k g )}\end{array}$ & $\begin{array}{c}\text { BMI } \\
\left(\mathbf{k g} / \mathbf{m} \_\right)\end{array}$ & $\begin{array}{c}\text { Diastolic blood } \\
\text { pressure } \\
(\mathbf{m m H g})\end{array}$ & $\begin{array}{c}\text { Systolic blood } \\
\text { pressure } \\
(\mathbf{m m H g})\end{array}$ & $\begin{array}{c}\text { Heart rate } \\
(\mathbf{b e a t s} / \mathbf{m i n})\end{array}$ & $\begin{array}{c}\text { Psycho- } \\
\text { technical test } \\
(\mathbf{\%})\end{array}$ \\
\hline \multirow{2}{*}{ Female } & 15 & 1.53 & 53.3 & 22.68 & 74.2 & 110.9 & 77.4 & 75.55 \\
& \pm 0.64 & \pm 0.05 & \pm 11.56 & Normal & \pm 12.73 & \pm 15.67 & \pm 10.33 & \pm 12.59 \\
Male & 15 & $\mathbf{1 . 6 0}$ & 55.8 & 21.95 & $\mathbf{8 8 . 7}$ & 121.9 & $\mathbf{6 5 . 5}$ & 66.51 \\
& \pm 0.72 & $\mathbf{\pm 0 . 0 9 *}$ & \pm 5.77 & Normal & $\mathbf{\pm 2 1 . 4 3 *}$ & \pm 28.66 & $\mathbf{\pm 1 2 . 4 5 * *}$ & \pm 21.81 \\
\hline
\end{tabular}

Table IV. Comparison of overall results (mean \pm standard deviation) for morphological and physiological patterns and of attention and perception assessments between the female students from Arica and from Putre $(* \mathrm{p}<0.05 ; * * * \mathrm{p}<0.001)$.

\begin{tabular}{lcccccccc}
\hline District & $\begin{array}{c}\text { Age } \\
(\mathbf{y} \text { ears })\end{array}$ & $\begin{array}{c}\text { Stature } \\
(\mathbf{m})\end{array}$ & $\begin{array}{c}\text { Weight } \\
(\mathbf{k g})\end{array}$ & $\begin{array}{c}\text { BMI } \\
\left(\mathbf{k g} / \mathbf{m} \_\right)\end{array}$ & $\begin{array}{c}\text { Diastolic blood } \\
\text { pressure } \\
(\mathbf{m m H g})\end{array}$ & $\begin{array}{c}\text { Systolic blood } \\
\text { pressure } \\
(\mathbf{m m H g})\end{array}$ & $\begin{array}{c}\text { Heart rate } \\
(\mathbf{b e a t} / \mathbf{m i n})\end{array}$ & $\begin{array}{c}\text { Psycho- } \\
\text { technical test } \\
(\mathbf{\%})\end{array}$ \\
\hline Arica & 15 & 1.61 & 58.5 & 22.76 & 82.9 & 123.2 & 82.4 & 82.21 \\
& \pm 0.89 & \pm 0.06 & \pm 6.91 & Normal & \pm 11.64 & \pm 9.92 & \pm 11.65 & \pm 9.36 \\
Putre & 15 & $\mathbf{1 . 5 3}$ & $\mathbf{5 3 . 3}$ & 22.68 & $\mathbf{7 4 . 2}$ & $\mathbf{1 1 0 . 9}$ & 77.4 & $\mathbf{7 5 . 5 5}$ \\
& \pm 0.64 & $\mathbf{\pm 0 . 0 5 *}$ & $\mathbf{\pm 1 1 . 5 6 *}$ & Normal & $\mathbf{\pm 1 2 . 7 3} *$ & $\mathbf{\pm 1 5 . 6 7 * * *}$ & \pm 10.33 & $\mathbf{\pm 1 2 . 5 9 *}$
\end{tabular}


Table V. Comparison of overall results (mean \pm standard deviation) for morphological and physiological patterns and of attention and perception assessments between the male students from Arica and from Putre $(* \mathrm{p}<0.05 ; * * \mathrm{p}<0.01)$.

\begin{tabular}{lcccccccc}
\hline District & $\begin{array}{c}\text { Age } \\
(\mathbf{y} \text { ears })\end{array}$ & $\begin{array}{c}\text { Stature } \\
(\mathbf{m})\end{array}$ & $\begin{array}{c}\text { Weight } \\
\mathbf{( k g )}\end{array}$ & $\begin{array}{c}\text { BMI } \\
\left(\mathbf{k g} / \mathbf{m} \_\right)\end{array}$ & $\begin{array}{c}\text { Diastolic blood } \\
\text { pressure } \\
(\mathbf{m m H g})\end{array}$ & $\begin{array}{c}\text { Systolic blood } \\
\text { pressure } \\
(\mathbf{m m H g})\end{array}$ & $\begin{array}{c}\text { Heart rate } \\
\text { (beats/min) }\end{array}$ & $\begin{array}{c}\text { Psycho- } \\
\text { technical test } \\
(\mathbf{\%})\end{array}$ \\
\hline Arica & 15 & 1.67 & 65.7 & 23.27 & 81.7 & 126 & 74.9 & 82.45 \\
& \pm 0.66 & \pm 0.07 & \pm 13.83 & Normal & \pm 10.59 & \pm 14.61 & \pm 12.76 & \pm 12.46 \\
Putre & 15 & $\mathbf{1 . 6 0}$ & $\mathbf{5 5 . 8}$ & 21.95 & 88.7 & 121.9 & $\mathbf{6 5 . 5}$ & $\mathbf{6 6 . 5 1}$ \\
& \pm 0.72 & $\mathbf{\pm 0 . 0 9 *}$ & $\mathbf{\pm 5 . 7 7 * *}$ & Normal & \pm 21.43 & \pm 28.66 & $\mathbf{\pm 1 2 . 4 5 *}$ & $\mathbf{\pm 2 1 . 8 1 *}$ \\
\hline
\end{tabular}

\section{DISCUSSION}

Attention is the central process involved in the control and execution of actions. Attention selects sensory information and mental processes to structure a particular action and is related to multiple processes of daily life, from learning, in all its aspects, to the decision to develop a plan of action (Pinel, 2007; Verges).

Perception describes both the action and the result of perceiving, i.e. having the ability to receive through the senses diverse images, impressions or external sensations, or to understand and to know something (Pinel). It is commonly believed that attention and perception are hardest to reach in communities that reside at high altitudes above the sea level, since living in high altitudes exposes our body to lower oxygen pressure (Virués-Ortega et al., 2006).

Altitude has a great impact on the populations exposed to it as was shown by the results obtained in this investigation evaluated through the Psychotechnical Test of Attention and Perception (psychometric test). Students from Putre (male and female) showed lower rates of achieved attention than the subjects (male and female) from Arica located at sea level. Wilson et al. (2009), have shown deterioration in arithmetic, memory, language, perception, learning, cognitive flexibility and psychomotor skills as altitude increases. Besides, the altitude environment causes an elevated number of changes in the composition of the blood, thus affecting the brain and other organs of our body (Kaur \& Ling, 2008).

Regarding body mass index (BMI), current Chilean reports state that there is an increase in the rate of obesity in the country, establishing that Chile faces an alarming increase in this situation even reaching levels comparable to the United States (Vio, 2005). This study shows that the high altitude population has lower weight and height than the population from sea level locations (Arica), similar to the study by Espinoza-Navarro et al. (2009) in an infantile population living in high altitude cities versus children living at sea level.
Cardiac patterns reflect a decrease in heart rate both in males and females living in high altitudes, this decrease being significant in males. In females from high altitude, a significant decrease in both systolic and diastolic pressure when compared to females from Arica is also observed. Similar results were observed by Zhang et al., (2010) working with a high altitude Tibetan population, where males showed a significant decrease in heart rate.

High altitude produces a series of physiological responses that involves several changes that include adaptations of metabolic rate and respiratory, circulatory and cardiac systems to meet the requirements of oxygen, nutrients and waste disposal among others (Virués-Ortega et al., 2011).

Altitude is a multistressing environment where adaptive and genetic patterns are as important as altitude itself, with one of the first changes to take place is the hypoxic angiogenesis, which is controlled by genes such as hypoxia inducible factor-1 and angiopoietin-2 (LaManna et al.). The brain is very sensitive to environmental hypoxia and it has been shown that increasing altitude over 3700 meters causes a decrease in mitochondrial function, affecting the metabolism and thus causing qualitative changes in neuropsychological performance (Hogan et al.; Virués-Ortega et al., 2011). Yan et al. (2011), when comparing populations living at sea level with populations living in high altitude, determined that there was an increase in reaction time without observing changes in attention span and conclude that adaptive mechanisms in the nervous system ensure behavior conducts comparable between the two populations under study. Similar results are shown by Richardson et al. (2011) who determined that the dynamics of the metabolic demand is an adaptive mechanism that retains cognitive levels at high altitude. Importantly, not only the physiological and morphological aspects mentioned above cause attentional and good school performance problems; there are also contextual determinants such as family, community, school, in addition to the 
characteristics of each place from high altitudes with populations with longer adaptation time than others, with ethnicity, culture and a specific worldview -different from other Western populations (Brutsaert et al., 2003; Stuber $\&$ Scherrer, 2010). It is expected that these results generate better methodologies regarding how to deal with learning disabilities in conditions of high altitude, since attention is the very basis of learning.

\section{CONCLUSIONS}

The population of Putre (3,500 m.a.s.l. in the Chilean Altiplano) exhibits lower response indices in perception and attentional capacity when compared to students from Arica (2 m.a.s.l.). Male and female students from Putre exhibit significantly lower weight and stature than students from Arica. All subjects under study had normal BMI according to the standards of the Institute of Technology and Food. Male students from Putre (high altitude) have lower heart rates than their counterparts from Arica. Female students from Putre show a significant decrease in systolic and diastolic pressure. These results demonstrate that altitude not only causes changes in the morphological and physiological patterns, but it also affects nervous system behavior. However, further studies with more detailed instruments of psycho-perception are required that allow to differentiate adaptive effects over time in populations exposed to high altitude from those elements that are unique to ethnicity, culture and worldview.

\section{ACKNOWLEDGMENTS}

This research was supported by Universidad de Tarapacá through Major Project UTA: 4712-13.

ESPINOZA-NAVARRO, O \& GRAÚ, S. Efectos de la altura sobre patrones morfofisiológicos y en la capacidad atencional y de percepción en estudiantes de las comunas de Putre (3500 msnm) y de Arica (2 msnm), Chile. Int. J. Morphol., 32(2):593-598, 2014.

RESUMEN: La hipoxia de altura es un estrés que dispara varios mecanismos adaptativos, uno de ellos es como el cerebro responde frente a la falta de oxígeno. El objetivo de este trabajo fue determinar cambios en los patrones morfológicos, fisiológicos y en la capacidad de atención y precepción de población estudiantil que vive en altura y a nivel del mar. Ochenta estudiantes de entre 14 a 16 años de ambos sexos, pertenecientes a las Comunas de Putre $(3500 \mathrm{msnm})$ y Arica $(2 \mathrm{msnm})$ participaron de este estudio. Cada grupo con 20 mujeres y 20 hombres fue medido para determinar su peso, talla, IMC, frecuencia cardiaca, presión sistólica y diastólica. Posteriormente se les aplicó una prueba psicométrica de atención y percepción. Los resultados determinan que la población de Putre presenta menor peso y talla que los alumnos de Arica. Los hombres muestran una disminución significativa de la frecuencia cardiaca y las mujeres presentan una presión sistólica y diastólica menor que lo observado en la población a nivel del mar. Los niveles de respuesta en la prueba psicotécnica son significativamente más bajos en la población que vive en altura tanto en hombres como mujeres. Se concluye que la altura provoca cambios en los patrones morfológicos, fisiológicos y en la capacidad de respuesta en el test psicotécnico. Sin embargo se requieren de mayores estudios de psicopercepción que permitan delimitar los efectos que son propios de la etnia, cultura y la cosmovisión de los pueblos que viven en altura y los niveles de respuesta de esta población.

PALABRAS CLAVE: Altura; Altiplano; Capacidad Atencional; Psicometría; Chile.

\section{REFERENCES}

Bass, J.; Corwin, M.; Gozal, D.; Moore, C.; Nishida, H.; Parker, S.; Schonwald, A.; Wilker, R. E.; Stehle, S. \& Kinane, T. B. The effect of chronic or intermittent hypoxia on cognition in childhood: A review of the evidence. Pediatrics, 114(3):80516,2004

Beall, C. M. Two routes to functional adaptation: Tibetan and Andean high-altitude natives. Proc. Natl. Acad. Sci. U. S. A., 104(Suppl. 1):8655-60, 2007.

Brutsaert, T. D.; Parra, E. J.; Shiver, M. D.; Gamboa, A.; Palacios, J. A.; Rivera, M.; Rodriguez, I. \& León-Velarde, F. Spanish genetic admixture is associated with larger $\mathrm{V}\left(\mathrm{O}_{2}\right)$ max decrement from sea level to $4338 \mathrm{~m}$ in Peruvian Quechua. $J$. Appl. Physiol., 95(2):519-28, 2003.
Espinoza-Navarro, O.; Vega, C.; Urrutia, A.; Moreno, A. \& Rodríguez, H. Patrones antropométricos y consumo máximo de oxígeno (VO2) entre niños escolares chilenos aymaras y no aymaras de 10 a 12 años, que viven en altura (3500 msnm) y en la planicie (500 msnm). Int. J. Morphol., 27(4):1313-8, 2009.

Espinoza-Navarro, O.; Díaz, J.; Rodríguez, H. \& Moreno, A. Effects of altitude on anthropometric and physiological patterns in Aymara and non-Aymara population between 18 and 65 years in the province of Parinacota Chile (3.700 masl). Int. J. Morphol., 29(1):34-40, 2011.

Hochachka, P. W.; Clark, C. M.; Brown, W. D.; Stanley, C.; Stone, C. K.; Nickles, R. J.; Zhu, G. G.; Allen, P. S. \& Holden, J. E. 
The brain at high altitude: hypometabolism as a defense against chronic hypoxia? J. Cereb. Blood Flow Metab., 14(4):671-9, 1994.

Hogan, A. M.; Virués-Ortega, J.; Botti, A. B.; Bucks, R.; Holloway, J. W.; Rose-Zerilli, M. J.; Palmer, L. J.; Webster, R. J.; Baldeweg, T. \& Kirkham, F. J. Development of aptitude at altitude. Dev. Sci., 13(3):533-44, 2010.

Horbein, T. F. The high-altitude brain. J. Exp. Biol., 204(Pt. 18):3129-32, 2001.

Instituto Nacional de Estadísticas (INE). Estadísticas sociales de los pueblos indígenas en Chile - Censo 2002. Santiago de Chile, Maval Publicaciones, 2005.

Kaur, C. \& Ling, E. A. Blood brain barrier in hypoxic-ischemic conditions. Curr. Neurovasc. Res., 5(1):71-81, 2008.

LaManna, J. C.; Chavez, J. C. \& Pichiule, P. Structural and functional adaptation to hypoxia in the rat brain. J. Exp. Biol., 207(Pt. 18):3163-9, 2004.

Olivares, S. Prevención del peso y Obesidad. 2002. Disponible en: www.inta.cl/material_educativo/cd/5obesid.pdf

Pinel, J. Biopsicología. Madrid, Pearson, 2007.

Richardson, C.; Hogan, A. M.; Bucks, R. S.; Baya, A.; ViruesOrtega, J.; Holloway, J. W.; Rose-Zerilli, M.; Palmer, L. J.; Webster, R. J.; Kirkham, F. J. \& Baldeweg, T. Neurophysiological evidence for cognitive and brain functional adaptation in adolescents living at high altitude. Clin. Neurophysiol., 122(9):1726-34, 2011.

Stuber, T. \& Scherrer, U. Circulatory adaptation to long-term high altitude exposure in Aymaras and Caucasians. Prog. Cardiovasc. Dis., 52(6):534-9, 2010.

Vio D., F. Prevención de la obesidad en Chile. Rev. Chil. Nutr., 32(2):80-7, 2005.

Verges, C. Trastornos por deficit de atención e hiperactividad (TDAH). Importancia de la visión en el diagnóstico y su tratamiento. 2012. Disponible en: http://oftalmologiabarcelona.com/2012/03/14/trastornos-por-deficit-de-atencione-hiperactividad-tdah-importancia-de-la-vision-en-el-diagnostico-y-su-tratamiento/

Virués-Ortega, J.; Garrido, E.; Javierre, C. \& Kloezeman, K. C. Human behaviour and development under high-altitude conditions. Dev. Sci., 9(4):400-10, 2006.

Virués-Ortega, J.; Bucks, R.; Kirkham, F. J.; Baldeweg, T.; BayaBotti, A.; Hogan, A. M. \& Bolivian Children Living at Altitude project (BoCLA 06). Changing patterns of neuropsychological functioning in children living at high altitude above and below $4000 \mathrm{~m}$ : a report from the Bolivian Children Living at Altitude (BoCLA)study. Dev. Sci., 14(5):1185-93, 2011.
Wilson, M. H.; Newman, S. \& Imray, C. H. The cerebral effects of ascent to high altitudes. Lancet Neurol., 8(2):175-91, 2009.

Wolff, C. B. Cerebral blood flow and oxygen delivery at high altitude. High Alt. Med. Biol., 1(1):33-8, 2000.

Yan, X.; Zhang, J.; Gong, Q. \& Weng, X. Adaptive influence of long term high altitude residence on spatial working memory: an fMRI study. Brain Cogn., 77(1):53-9, 2011.

Zhang, J.; Yan, X.; Shi, J.; Gong, Q.; Weng, X. \& Liu, Y. Structural modifications of the brain in acclimatization to high-altitude. PLoS One, 5(7):e11449, 2010.

Correspondence to:

Prof. Dr. Omar Espinoza Navarro

Faculty of Sciences, Department of Biology

Universidad de Tarapacá

Avenida General Velásquez N 1775

Arica

CHILE

Email: oespinoz@uta.cl

Received: 30-01-2014

Accepted: 21-04-2014 